
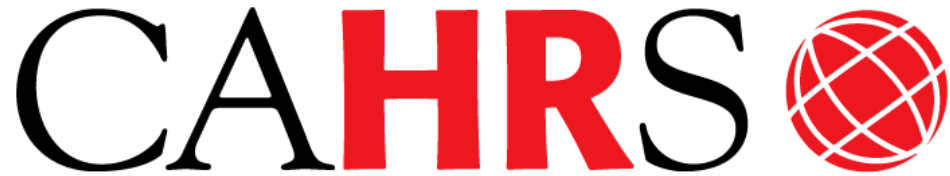

Center for Advanced Human Resource Studies

Uorhing Prperg 马erie马
CAHRS / Cornell University 187 Ives Hall

Ithaca, NY 14853-3901 USA

Tel. 607 255-9358

www.ilr.cornell.edu/CAHRS/

\title{
Minimizing Competition? Entry-level Compensation in Japanese Firms
}

\author{
Yoshio Yanadori \\ George T. Milkovich
}

Working Paper 03 - 20

CORNELL ifr school of Industrial and Labor Relations 


\title{
Minimizing Competition? Entry-level Compensation in Japanese Firms
}

\author{
Yoshio Yanadori \\ ILR School \\ Cornell University \\ 393 Ives Hall \\ Ithaca, NY14853-3901 \\ Tel: (607) 255-7622 \\ Fax: (607) 255-1836 \\ yy40@ cornell.edu
}

\author{
George T. Milkovich \\ Center for Advanced Human Resource Studies \\ ILR School \\ Cornell University \\ 393 Ives Hall \\ Ithaca, NY14853-3901 \\ Tel: (607) 255-7622 \\ Fax: (607) 255-1836 \\ gtm1@ cornell.edu
}

December, 2003

\begin{abstract}
http://www.ilr.cornell.edu/cahrs
This paper has not undergone formal review or approval of the faculty of the ILR School. It is intended to make results of Center research available to others interested in preliminary form to encourage discussion and suggestions.
\end{abstract}

Most (if not all) of the CAHRS Working Papers are available for reading at the Catherwood Library. For information on what's available link to the Cornell Library Catalog: http://catalog.library.cornell.edu if you wish. 


\begin{abstract}
This is the first empirical study of the determinants of pay for entry-level jobs among Japanese firms. Pay data of 1,382 companies obtained from the Nikkei survey was matched with company size, performance, industry, and foreign ownership data from Toyo Keizais Japan Company Handbook. We found that unlike the results based on U.S. data, company size is not related to entry-level pay. Firm performance is positively related, but its effect is minimal. Industry membership and foreign ownership are positively related. We believe that these findings highlight the influence of the Japanese employment context and information sharing in Japan. Implications for research and practice are discussed.
\end{abstract}

\title{
Acknowledgement
}

The authors also would like to thank Andrew Doyle, Hiroshi Kurihara, and Tetsu Hirasawa for their helpful comments and suggestions. 


\section{Minimizing Competition? Entry-level Compensation in Japanese Firms}

Japanese firms are noted for their lifetime employment (Abegglen, 1958; Dore, 1973; Morishima, 1995). Recent news accounts claim that Japanese firms can no longer maintain the lifetime employment system due to cost and competitive pressures. Yet recent empirical evidence reveals that job retention rates have not declined and lifetime employment appears to persist (Kato, 2001; Okazaki, 1997). While Japanese firms have been downsizing (Ahmadjian \& Robinson, 2002), they achieve this primarily through transferring employees to their subsidiaries and related firms, thus avoiding layoffs (Kato, 2001). Under the traditional Japanese system, college graduates typically join firms and expect to stay until the mandatory retirement age (typically 60 years old). Although firms occasionally make special arrangements (e.g., permanent transfer to subsidiaries or related firms, early retirement programs with large financial premiums), these programs usually target very senior employees. Several writers argue that due to the strong social expectations, Japanese firms seem unwilling to dismiss their employees (Sano, 1995). Moreover, legal precedents set by the Japanese courts make it extremely difficult for firms to terminate the employment relationship without the employees' consent (Morishima, 1995). Most college graduates therefore have strong expectations that their firms will retain them until they become very senior. Consequently, employment security remains a core employment policy in Japanese management (Kato, 2001; Morishima, 1995).

Given the persistence of long-term employment security, recruiting college graduates remains a critical issue in Japanese firms. It directly determines the quality of firms' human capital. While it is widely recognized that some human resource practices such as rigorous selection (e.g., structured interviews, cognitive tests) are effective in acquiring high quality human capital (Terpstra \& Rozell, 1993; Koch \& McGrath, 1996), some researchers argue that compensation systems are another key ingredient for successful recruitment (Barber \& Bretz, 2000; Olian \& Rynbes, 1984; Rynes, 1987). The potential effects of the multiple dimensions of 
compensation management (i.e., pay level, pay mix, pay structure) on applicants' job search behaviors have long been recognized, especially by compensation researchers in the U.S. (Barber \& Bretz, 2000; Rynes, 1987). Among all these dimensions, pay level for entry-level jobs is clearly an important influence to attract job applicants; higher pay level attracts more job applicants (Bretz \& Judge, 1994; Cable \& Judge, 1994; Powell, 1984), which increases the firms' probability of selecting higher quality applicants. In spite of these findings of past studies about the effects of compensation on attracting job applicants, limited research effort has been made on how firms actually determine their entry-level compensation. The paucity of entry-level pay research is especially true to Japan; little is known about how Japanese firms set their pay levels for their entry-level jobs, or how Japanese firms use pay to differentiate themselves while recruiting for entry-level jobs.

The primary purpose of our study is to understand the determinants of compensation for entry-level jobs for recent college graduates in Japan. Using publicly available data on base pay for entry-level jobs in 1,382 Japanese publicly traded firms, we analyze which factors influence pay levels for college graduates in Japan. Studies using U.S. data have reported that an individual employee's pay level is a function of personal characteristics (e.g., education, experience), job characteristics (e.g., job level, job family), organization characteristics (e.g., size, performance, industry membership), and external factors (e.g., labor market conditions) (e.g., Gerhart \& Milkovich, 1990). Geographic differences, including variations in cost of living, are also related to differences in entry-level pay (e.g., Milkovich \& Newman, 2002). Building on these findings in U.S. studies, we explore the determinants of entry-level pay in Japanese firms. While U.S. compensation studies typically incorporate three levels: individual-, organization-, and industry-level factors, our study focuses on organization- and industry-level factors as we are interested in how Japanese firms determine pay levels for new college graduates.

Our study makes three principal contributions. First, to our knowledge, this is the first empirical study of the determinants of pay levels for entry-level jobs in Japanese firms. In fact, there are few empirical studies that focus on entry-level pay even in the U.S. or in other 
countries. One of the few exceptions is Graham, Hotchkiss, and Gerhart (2000), which reported that various individual-level factors (e.g., gender, GPA, college major) and an industry-level factor (i.e., industry membership) influence entry-level pay. Thus, our study contributes not only to researchers and practitioners interested in Japanese management, but also to a broader audience interested in human resource management. Second, our focus on firm-level and industry-level factors warrants an investigation on how Japanese firms deal with external competitiveness issues. In this sense, our study adds some knowledge to cross-firm pay differentials research. Interestingly, Graham et al.'s (2000) study on entry-level pay did not include any firm-level factors, and thus, research is yet to be developed concerning how firms compete through compensation to attract job applicants. Finally, our study analyzes pay data from Japanese firms. Our effort to incorporate the Japanese employment context offers a comparative contrast to the past findings of U.S.-based literature. As well as empirical analysis, we provide a description of the Japanese firms' unique pay practice used to determine their pay levels. Specifically, we believe that established Japanese firms only exchange pay information with their market competitors rather than sharing it through third parties such as compensation consulting firms. We argue that the nature of this information exchange, in which representatives meet to discuss and share pay data, helps explain the small variability of entrylevel pay across firms.

\section{Compensation Systems In Japanese Firms}

\section{Traditional Japanese Compensation System}

Under the traditional Japanese system, employee compensation has four forms: base pay, bonuses, benefits, and allowances. Base pay accounts for 60 to 80 percent of employees' monthly pay. Bonuses are typically paid twice a year (i.e., summer and winter), and the amount is calculated by multiplying employees' monthly base pay by a multiplier. A recent survey reports that the average multiplier was 4.72 (2.21 in summer and 2.51 in winter) in 2000 for 
workers in administrative positions (National Personnel Authority, 2001). Social security, unemployment insurance, and workers' compensation are legally mandated benefits in Japan. Firms provide additional benefits such as corporate pension, company housing, and company private banking.

Allowances for housing, dependents, and commuting are intended to support employees' standard of living. The size of each allowance is generally based on employee need (e.g., number of dependents, the cost of commuting) regardless of job levels. Stock options only recently became legal (June 1997), but a recent survey conducted jointly by Towers Perrin Tokyo and Nikko Cordial Securities (2002) reports that about 30 percent of public firms in Japan have already introduced stock options. No reliable statistic is currently available concerning its use for non-managerial employees. Some researchers note that Japanese labor law, tax system, and social security system encourage employers to use allowances and bonuses rather than base pay (Bloom, Milkovich, \& Mitra, 2000) ${ }^{1}$. Nevertheless, base pay still plays a major role in the Japanese compensation system because it accounts for a large proportion of employee compensation and the size of many other pay components (e.g., bonuses, overtime allowance, retirement allowance) is a function of one's base pay.

Base pay, under the traditional Japanese pay system, emphasizes the person rather than the job (Milkovich \& Newman, 2002). "Vocational ability qualification system" (Sano, 1995: 120) is a common approach to develop firms' pay structures. The basic premise is that the accumulation of firm specific experience increases employees' knowledge and abilities; thus base pay increases according to employees' tenure. In some Japanese firms, the link between employee tenure and base pay is more direct; base pay is divided into two portions, which reflect employees' job qualifications and tenure (Milkovich \& Newman, 2002: 552-553; Shibata, 2000: 297-304). Some Japanese researchers also argue that through the seniority system, Japanese firms design their pay systems in such a way that they pay junior employees less than their productivity, while they pay senior employees more than their productivity (Mishina \& Inaba, 1985). Even though pay and productivity do not exactly match in each stage of employees' 
career, accumulated total productivity and total compensation in employees' entire career are believed to be equal. This design complements the Japanese long-term employment security by discouraging employees' turnover. Employees are motivated to stay until they become senior and get relatively generous pay, which makes up for their lower pay while they are more junior.

\section{Recent Modifications in Japanese Compensation System}

The traditional seniority-based system, coupled with long-term employment security, worked under economic growth because adding college graduates with their relatively lower compensation cost kept the average labor costs of the workforce controlled (Abegglen, 1957). However, once economic conditions deteriorated and firms began reducing the flow of new hires into their workforces, average tenure increased, followed by increasing average labor costs. Aging workforces generate increasing average compensation, which may exceeds actual productivity. Consequently, many firms have reportedly begun to weaken the link between pay and employees' tenure (Schlender \& Kano, 1994; Shibata, 2000). Shibata (2000) reported a modification of compensation system in a Japanese firm in reaction to the slowdown of Japanese economic growth. The firm changed its performance evaluation system in 1997, which resulted in greater pay differentials among employees of the same age. For instance, while the monthly pay differential (maximum - minimum) for 50-year-old employees was 110,000 yen before the change, it increased to 200,000 yen after the change.

We also conducted interviews with HR professionals of two Japanese firms that recently transformed their compensation systems: a large electric utility company and one of the world's largest manufacturers of copiers. In response to the Japanese government's deregulation policy of the electric power supply, the utility company began diversifying into internet services. Despite these efforts, its operating profit has slightly decreased. After a sharp decline in profitability in 1998, the copier company has experienced a steady recovery. Managers in both companies labeled their compensation transformation as "from traditional Japanese system to American system," by which they mean their firms' new systems reflect the employees' knowledge and abilities to a greater extent than under the seniority system. However, their basic 
pay structures have not been transformed drastically. Rather, the rates of promotion have been modified to more directly reflect managers' evaluation of employees' knowledge and abilities. Through performance appraisals, employees judged to exhibit greater knowledge and abilities will be promoted early in their career. Promotions are associated with greater pay increases; consequently employees with greater knowledge and abilities will earn more. As a result, differentiation of the rate of promotion eventually leads to the differentiation of pay between employees with the same length of tenure but different knowledge and abilities. Both of these firms still maintain lifetime employment practices; their permanent employees expect to remain in these firms for their entire careers. They also continue to employ new college graduates as a major source of their permanent employees. It appears that the primary effort of these "Americanized" changes in compensation systems means a greater differentiation in pay. By replacing an automatic pay increase tied to each employee's tenure with increased differentiation based on knowledge and performance, employers appear to be seeking to control the increasing labor cost associated with an aging workforce.

In sum, the transformation in these companies is best described as differentiation based on promotion within a seniority-based pay structure. In a sense, the scaffolding has remained; the rate at which higher-ability employees advance through it has increased while the advancement of less productive employees has been more difficult. We fully recognize our interviews are highly anecdotal; however, we believe that they do offer some contextual richness to better inform our analysis.

\section{Entry-level Compensation in Japan}

In Japan, firms rarely differentiate the size of base pay among newly hired employees with the same educational background (see pages 552-553 in Milkovich and Newman, 2002 or pages 297-304 in Shibata, 2000). Despite Japanese firms' recent effort to make a greater differentiation of employees' pay, they have not started to make any visible differentiation among newly hired employees. Japanese firms develop pay tables and assign all new employees to the entry rank. The type of degree (e.g., law, economics, engineering) affects the 
type of work an applicant is assigned. For bachelor's degree holders, new employees are typically assigned to administrative jobs or technical jobs, and different pay tables are applied to these different job families. Yet, new employees in the same job family are all assigned to the same rank and paid equal base pay regardless of the status of the university they graduated from (i.e., elite school vs. others), the type of degree (e.g., economics, law, humanities), or their GPA. Consequently, all new administrative employees with the same degree receive identical

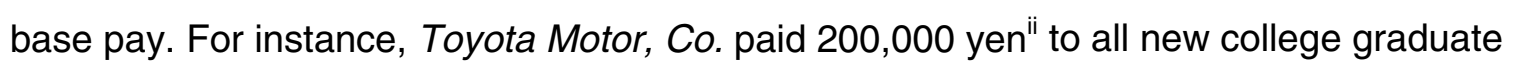
employees assigned to administrative positions as monthly base pay in 2001 (Nihon Keizai Shimbun, 2001). In the course of time after observing junior employees' performance, firms differentiate the rate of their promotion, which results in the subsequent difference in pay level among employees, but it becomes apparent only after one becomes a middle-senior level employee (e.g., 6-8 years experience in the firm).

\section{Theory Development and Hypotheses}

\section{Theoretical Background}

We reviewed contemporary theoretical explanations of firms' pay setting behavior. The neoclassical economic model begins with a perfectly competitive market; wages are determined based on labor supply and demand in the market, and workers and firms are regarded as price takers (Ehrenberg \& Smith, 1997). At the same time, labor economists and management researchers have long recognized that wages differ among employees and firms. Several explanations based on considerable research evidence are offered.

One line of research focuses on labor supply. According to human capital theory (Becker, 1993), education and training improve workers' productivity by improving their general human capital. Consequently, firms offer different wage levels depending on workers' productivity. Countless studies, not only in the U.S. but also in many countries, have empirically confirmed that a higher level of education is associated with higher wages (Card, 1999). The accumulation 
of firm-specific human capital, typically measured by the length of tenure has also been found to be positively associated with wage (Brown, 1989; Topel, 1991). HRM researchers also recognize that the labor force is heterogeneous in terms of knowledge, skills, and abilities (KSAs) relevant to production (e.g., Wright, MacMahan, \& MacWilliams, 1994). The difference in KSAs is associated with the difference in workers' contribution, which leads to the differences in pay level across employees.

A second line of research focuses on the demand side, or characteristics of jobs. Modern organizations generally have hierarchical structures. Job level (e.g., associates, managers, executives), which reflects differences in responsibility, obviously influences pay levels. Differences in pay level across job families (e.g., administrative, technical, R\&D) due to the differences in contribution to production are also widely reported in the U.S. (Milkovich \& Newman, 2002). Arguably, the idea that pay levels differ across job levels and families is regarded as self-evident. Consequently, these factors are typically treated as control variables. Research also shows that pay structure, pay differentials across job levels and job groups, varies among firms (Bloom, 1999; Pfeffer \& Davis-Blake, 1995). Thus, two workers employed by different firms could be paid differently even if their job levels and job families are identical. This relates to the third line of research, which focuses on inter-firm difference.

A large number of studies both in labor economics (e.g., Groshen,1991; Groshen, \& Levin, 2000) and management (e.g., Gerhart \& Milkovich, 1990) have observed stable differences in pay level across firms. Firm size appears to explain the difference in pay level across firms. Several explanations are offered. First, large firms may be more likely to offer training opportunities for their existing employees. As a result of company-provided training, employees in large firms become more productive, which is associated with higher pay level (Ehrenberg \& Smith, 1997). Second, it may be more difficult to monitor employees' behaviors in large firms, and thus pay levels are higher than average to discourage the employees' poor performance for fear of losing their higher-paid jobs (Shapiro \& Stiglitz, 1984). Finally, because the production processes in large firms are more interdependent, job vacancies become more costly. 
Consequently, large firms may be more willing to set higher pay to deter their employees from quitting.

Firm performance is also reported to explain differences in pay level across firms. The link between firm performance and pay is based on agency theory (Eisenhard, 1989; Jensen \& Meckling, 1976), which offers a normative proposition that pay should be linked to firm performance. However, many empirical studies have reported insignificant or low correlation, even if significant, between firm performance and top executives' compensation (Jensen \& Murphy, 1990; Kerr \& Bettis, 1987). A recent meta-analysis by Tosi, Werner, Katz, and GomezMejia (2000) reported that only 5 percent of the variance of CEO pay level is explained by firm performance, whereas more than 40 percent of its variance is explained by firm size.

In addition to firm size and performance, some compensation researchers claim that firms adopt different strategies regarding pay levels. Gerhart and Milkovich (1990) reported that firms exhibited a distinct difference in pay level, which was stable over time even after controlling for other relevant factors (e.g., human capital, job level, firm size, performance, industry). They argued that firms have discretion in designing their pay systems, and the difference in pay level reflects firms' pay strategies, other factors considered. Indeed, compensation textbooks in the U.S. (e.g., Martocchio, 2001; Milkovich \& Newman, 2002) argue that setting pay level as relative to market pay level (i.e., lead, lag, match) is a critical strategic decision; entire chapters are devoted to discussion on how to determine competitive position in the market.

Finally, industry membership is another factor found to be related to pay level in U.S. research (e.g., Krueger \& Summers, 1988). Differences in industry membership reflect differences in the technology used and influence the productivity of the workforce (Milkovich \& Newman, 2002). Thus, industry, through technology and productivity, is related to differences in pay in the U.S. In addition, the differences in technology result in differences in firms' ability to bear the cost of turnover and to monitor workers (Krueger \& Summers, 1988). Such differences lead to the difference in pay level across industries; firms in one industry may find that turnover is more costly than firms in another industry, so that they set higher pay levels to discourage 
turnover. Translating all the above theoretical perspective into practice, U.S. employers collect competitors' market pay level information by participating in compensation surveys conducted by consulting firms. Firms generally pay greater attention to the pay levels of the firms in the same industry, who compete in the same labor market to attract top talent. As a result, firms' pay levels tend to reflect industry patterns, yet there is still variation within an industry (Gerhart, 2000).

It is important to note that much of the research on and theory related to pay determination has been developed in the U.S. Considering the difference in employment contexts across countries, there is no guarantee that these explanations apply to the behaviors of the employers and employees in other countries. Therefore, when developing our hypotheses about the determinants of entry-level pay in Japan, we discuss how directly the above explanations translate into the Japanese employment context and their usefulness in understanding entry-level pay determination in Japan.

\section{Entry-level pay in Japanese firms - Hypotheses}

Though past U.S.-based research suggests that a number of factors influence pay level, studying entry-level pay for administrative jobs in Japanese firms allows us to focus on firm-level and industry-level factors. This is possible because a Japanese firm pays the same level of base pay to all its new college graduates in the same job groups. Since there is no variance in entry-level base pay within a firm, our independent variables include firm-level and industry-level variables.

The first factor that is firm size. As already noted, quite a few U.S.-based studies have confirmed that firm size is positively related to pay level, and thus the relationship between firm size and pay level appears to be unambiguous. In Japan, research has also found a positive effect of firm size to wage although virtually all studies have used categorical variables (e.g., small-medium-large. See Tachibanaki, 1996, for example), so that it is not clear whether the relationship between firm size and wage is linear as is found in U.S. studies. When it comes to entry-level jobs, however, research is not unambiguous concerning the relationship between 
firm size and pay level either in the U.S. or Japan due to the limited number of studies focusing on the effects of firm-level factors on entry-level pay.

Our study's focus on Japanese firms makes it harder to simply apply the U.S.-based studies' explanations to the Japanese setting because the basic premises of the theoretical explanations may not hold in the Japanese context. The first explanation is that employees in large firms are more productive due to the more frequent company-provided training. However, new college graduates rarely have a chance to receive company-provided training before joining their firms; consequently, their productivity will not be influenced by the manner that the first explanation suggests. The second explanation is also questionable in the Japanese context. Large firms, which face monitoring difficulties, will pay more to discourage their employees from shirking out of fear of losing higher-paid jobs. However, given Japanese employers' difficulty in laying off their employees, employees in Japan may be less likely to be concerned about the termination of their employment contracts due to low performance. Consequently, higher pay level may not be an effective tool to discourage shirking. The third explanation argues that high interdependence among jobs leads employers to find turnover more costly, and consequently firms offer higher pay to discourage employee turnover. Arguably, large Japanese firms may find it unnecessary to set higher pay even though their production processes are highly interdependent because Japanese employees have a strong tendency to stay within a single firm for their entire work carriers. Furthermore, the second explanation (i.e., discourage shirking) and third explanation (i.e., discourage turnover) are more concerned with motivating and retaining existing employees. These explanations are less relevant to attracting job applicants, which compensation managers focus on when setting entry-level pay.

All three explanations, which are derived from U.S.-based studies, face challenges when exported to the Japanese employment context. Because of the weak theoretical relevance of the effect of firm size on entry-level base pay in Japan, our first hypothesis refutes the significant relationship between firm size and entry-level base pay found in Japan. 
Hypothesis 1: In the Japanese context, firm size is not positively related to entry-level base pay.

The second potential determinant is firm performance. The notion that pay level should be linked with firm performance is intuitive, indeed even commonsensical. However, there is only limited study of the firm performance-pay relationship using Japanese data. Kato and Rockell (1992) explored the determinants of CEO compensation, and failed to find a significant relationship between firm performance and CEO compensation. While our study focuses on entry-level rather than CEO, it is important to note that virtually all of the past CEO compensation studies analyzed compensation data that included incentives (e.g., short-term incentives and long-term incentives) as well as base pay, or salary. Since incentives account for much of the relationship between CEO pay and firm performance, the positive relationship between base pay and firm performance is much weaker. The weak relation between CEO pay and firm performance raises questions about the relationship between non-managerial pay and firm performance. This is especially true of Japanese firms.

The argument that firms with better performance pay more becomes more problematic when we focus on entry-level pay in Japan. If the Japanese still have a strong expectation of staying in a single firm for their entire professional careers, then college graduates will pay greater attention to firms' potential stability, and they will be reluctant to join firms that may have a high probability of failure. Information on each firm's current business performance is easily accessible to college graduates. As a result, fewer college graduates may be interested in joining firms whose current business performance is low. From Japanese employers' viewpoint, acquiring high quality college graduates is critical for firms' future success. Consequently, lowperformance firms may try to attract more recruits by offering above market entry-level pay or greater incentives to compensate for higher business risk. Therefore, it is plausible that firm performance and entry-level pay have a negative relationship. 
In sum, current theory and research do not clearly address whether there is any relationship between firm performance and entry-level pay in a socio-economic context such as Japan's. Further, we found no evidence in either the U.S. or Japan which directly examined the relationship between firm performance and entry-level pay. Consequently, we predict that entrylevel pay is not positively related to firm performance in Japan.

Hypothesis 2. In the Japanese context, firm performance is not positively related to entry level base pay.

The third potential factor is industry. Consistent with evidence from the U.S. data, we expect that industry membership influences the pay level for entry-level jobs in Japan, but through different mechanisms than in U.S. firms. What makes the Japanese compensation practice different from the U.S. practice is the manner in which traditional Japanese firms share compensation information, including some future pay information, directly with their market competitors. Milkovich and Newman (2002) allege that this information exchange process is not openly discussed, and thus we raised the subject during personal interviews with compensation managers. One interviewee, who had worked for a large, established Japanese electronic manufacturing firm and is currently working for a subsidiary of a large U.S. financial firm in Tokyo as a vice president of compensation, described his experience working for the traditional Japanese firm. He reported that Japanese compensation managers meet privately with compensation managers in other major firms in the same industry and exchanged detailed pay information. The information exchanged include not only past history, but also future pay decisions such as the expected increase in the merit pay budget and entry-level base pay for college graduates. He explained that hiring new college graduates was very important for Japanese HR managers, and therefore his firm and its market competitors were interested in how much other firms would pay. Another interviewee in a large manufacturer of copiers verified that detailed pay information including future decisions is exchanged with market competitors. 
We believe that Japanese information sharing differs significantly from the market survey practices of U.S. companies. U.S. companies do share historic pay data, but do not discuss or reach mutual agreements over future compensation. Such behavior in the U.S. is open to charges of price fixing and subject to antitrust laws. One recent suit alleged that such behaviors among oil drilling companies were in violation of U.S. antitrust laws (Walsh 2001). An out-ofcourt settlement was reached. U.S. firms do exchange data through compensation consulting companies; only aggregated information is provided to participating firms in order to maintain confidentiality of specific company data.

Since information exchange occurs between traditional Japanese firms that compete in the same product markets, we expect that industry membership will account for the variability in pay level. Given our interviewees' comments on the exchange of pay information, including the information on expected entry-level pay, we expect the influence of industry membership on entry-level base pay to be strong. Admittedly, this is anecdotal evidence. We do not have evidence that all firms in Japan are privately exchanging information. However, we believe that these anecdotes offer insights and are legitimate sources of ideas. If pay information exchange practices are common among large, traditional Japanese firms, we expect the influence of industry membership to be especially strong for large firms.

Hypothesis 3a: In the Japanese context, industry membership is significantly related to entry-level base pay.

Hypothesis 3b: In the Japanese context, industry membership explains the variance in entry-level base pay for larger firms more than it explains the variance in entry-level base pay for smaller firms.

If the information exchange is an important and insular practice among traditional Japanese firms, then newly emerging firms face difficulties in collecting relevant market compensation information. Indeed, to our knowledge no compensation consulting firm operating 
in Japan offers market compensation survey services to Japanese firms. Yet, as noted earlier, such market surveys are important services offered by consultants in the U.S. and many multinational corporations (MNCs) around the world. The demand for such information from traditional Japanese firms is very weak, presumably because it is obtained via industry networks. Consequently, firms without access to information exchange networks will exhibit differences in their pay level from traditional Japanese firms. In particular, because subsidiaries of foreign MNCs are regarded as outsiders by traditional Japanese firms, they will pay differently. The difficulty in collecting relevant labor market information in foreign countries is common. Many subsidiaries of foreign MNCs reportedly overpay due to the lack of market pay data (Evans, Pucik, \& Barsoux, 2002). In addition, some researchers observe that foreign MNCs in Japan must pay more to attract top talent. Their argument is that Japanese workers prefer traditional Japanese firms. Moreover, the Japanese public perceives that foreign MNCs are more likely to lay off their employees. To offset this disadvantage, foreign MNCs offer higher entry-level pay.

In sum, several reasons suggest that foreign MNCs' pay is higher than that of traditional Japanese firms. Since the stock of large, established Japanese firms are usually held by their keiretsu partners (Namiki, 1999), the greater the proportion of a firm's stock held by foreign investors or foreign firms, the less likely the firm is regarded as an established, traditional Japanese firm. Consequently, we hypothesize that the greater the proportion of firms' stock held by foreign stockowners, the higher the entry-level base pay in Japan.

Hypothesis 4. In the Japanese context, foreign ownership is positively related to entrylevel base pay.

\section{Methods}

\section{Data}

The information on base pay for entry-level jobs was obtained from the Nihon Keizai Shimbun (Nikkei), a major financial newspaper in Japan. Every year the Nikkei compiles a 
special report on the job market for new college graduates. While its primary purpose is to report the number of new employees each firm hires, it also reports the level of base pay for new employees for each firm. The report is made based on the survey the Nikkei sent to firms from a variety of industries. In the 2001 survey, the Nikkei sends the questionnaire to 3,875 firms and got responses from 2,456 firms. Some firms reported the previous year's pay information, and others did not provide pay information at all. We combined the reports in the Nikkei (2001) and the Nikkei (2002) to create year 2001 data for our analysis. We used the level of monthly base pay as the dependent variable.

Data on firm size, firm performance, industry membership, and the proportion of firms' stock held by foreign stockowners was collected from Toyo Keizai's Japan Company Handbook. We used the number of employees and return on assets (ROA) for the proxies for firm size and firm performance, respectively. While different compensation studies use different size measures (e.g., assets, sales, total employment), we believe that the number of employees is the most relevant measure in our study because theoretical explanations between firm size and pay level are related to the number of employees (i.e., monitoring difficulty, interconnectedness of jobs). Prior research shows that ROA is an appropriate performance measure for Japanese firms (Gedajlovic \& Shapiro, 2002). For foreign ownership, the Japan Company Handbook includes information on the proportion of foreign stockowners, which we used as the proxy. We took a one-year lag for firm size, firm performance, and foreign ownership, and thus used the data as of the end of the fiscal year 2000. For industry membership, we categorized based on industry classification by the Japan Company Handbook, which classifies Japanese firms into 34 categories. Then we created 33 industry dummy variables. The base industry is Wholesale (see Table 1 for detail). We controlled for geographic areas of firms' location. Tokyo and Osaka are famous for their high cost of living (William Mercer, 2002). The Japanese statistics bureau's survey shows that consumer prices in Tokyo and Osaka are higher than the national average by 9.5 percent and 8.0 percent, respectively. Due to the high cost of living, firms operating in these areas may pay more than those operating in other areas. We created two dummy variables for 
two major urban areas that include Tokyo and Osaka: Kanto (includes Tokyo, Chiba, Kanagawa, and Saitama prefectures) and Kansai (includes Osaka, Kyoto, Shiga, Hyogo, Nara, and Wakayama prefectures) based on company headquarters location. While the Nikkei's reports (2001; 2002) cover both public and private firms, the Japan Company Handbook only contains information on publicly traded firms. Therefore, our dataset is composed of only public firms. Our collection effort yielded 1,382 firms with usable data for the analysis. Logarithmic transformation was applied to firm size because of its skewed distribution.

\begin{tabular}{|c|c|}
\hline \multicolumn{2}{|c|}{$\begin{array}{c}\text { Table 1 } \\
\text { Industry Classification Information }\end{array}$} \\
\hline Industry & Number of firms \\
\hline Air Transport & 2 \\
\hline Banks & 63 \\
\hline Chemicals & 104 \\
\hline Communication & 3 \\
\hline Construction & 101 \\
\hline Electric Power \& Gas & 13 \\
\hline Electrical Machinery & 130 \\
\hline Fishery, Agriculture \& Forestry & 5 \\
\hline Foods & 61 \\
\hline Glass \& Ceramics & 30 \\
\hline Insurance & 5 \\
\hline Land Transport & 37 \\
\hline Machinery & 100 \\
\hline Marine Transport & 15 \\
\hline Metal Products & 28 \\
\hline Mining & 20 \\
\hline Miscellaneous Finance & 2 \\
\hline Nonferrous Metals & 22 \\
\hline Oil \& Coal Products & 6 \\
\hline Other Products & 40 \\
\hline Pharmaceuticals & 30 \\
\hline Precision Instrument & 20 \\
\hline Pulp \& Paper & 15 \\
\hline Real Estate & 25 \\
\hline Retail & 119 \\
\hline Rubber Products & 11 \\
\hline Securities \& Commodity Futures & 14 \\
\hline Services & 96 \\
\hline Steel Products & 23 \\
\hline Textiles \& Apparel & 35 \\
\hline Transport Equipment & 57 \\
\hline Warehousing \& Harbor Transport Services & 23 \\
\hline Wholesale & 127 \\
\hline Total & 1382 \\
\hline
\end{tabular}




\section{Model Estimation}

To find the determinants of entry-level base pay, we used an ordinary least square model with the following equation:

$$
\begin{array}{r}
\text { Entry-level Base Pay } \left.=\beta_{0}+\beta_{1} \text { (Kanto }\right)+\beta_{2} \text { (Kansai) }+\beta_{3}(\text { Firm size })+\beta_{4}(\text { Firm } \\
\text { performance } \left.)+\beta_{5-37} \text { (Industry dummy variables }\right)+\beta_{38} \text { (Foreign ownership). }
\end{array}
$$

Our hypotheses 1 and 2 oppose the positive effects of firm size and firm performance on entrylevel pay. We note that these two hypotheses are different from the statement that there is no effect of firm size and firm performance on entry-level pay in terms of statistical techniques required to prove the relationship. To confirm the latter statement, we would have to accept the null hypothesis that the effect of firm size and firm performance is zero (Frick, 1995; Cortina, 2001). This study's approach is different; we are interested in whether the positive effects of firm size and firm performance to employee pay levels found in U.S.-based studies are also observed in entry-level pay in Japanese firms. Therefore, the failure to reject the null hypotheses that the effects of firm size and firm performance on entry-level pay are zero suffices for the support of our hypotheses 1 and 2.

We examined $\beta_{38}$ to test the effect of foreign ownership (hypothesis 4). To test hypotheses $3 a$, and $3 b$, which are associated with the effect of industry membership, we used a stepwise regression and calculated the change in $\mathrm{R}^{2}$. First, we included only control variables (Kanto and Kansai). Next, we added firm size and firm performance to the model. Then we included industry dummy variables. Finally we included the foreign ownership variable. We examined whether adding industry dummy variables significantly improves the regression model to test hypothesis $3 a$, which states that industry membership is associated with entry-level base pay.

We created two datasets from our original dataset to test hypothesis $3 \mathrm{~b}$, which states that industry membership explains entry-level base pay of large firms more than that of small firms. One dataset includes only large firms; those greater than one standard deviation above the 
mean firm size in our original dataset. The other is made up of only small firms; those smaller than one standard deviation below the mean. Stepwise regressions were run on each and we compared the change in $R^{2}$ when industry dummy variables were added (See Table 4 and 5). Although this treatment limits the variability of firm size, the sample is still large enough for both datasets (214 firms in the "large firm" dataset and 211 firms in the "small firm" dataset).

\section{Results}

\section{Regression Analyses}

Table 2 contains a summary of descriptive statistics, along with their intercorrelations. The regression analysis results are displayed in Table 3 . The first column of results is from the model in which only control variables (Kanto and Kansai) were included as independent variables. The second column contains the results from the model that included firm size and firm performance as well as two geographic variables. The third column displays the results from the model that included 33 industry dummy variables. Finally, the leftmost column shows the results from the full model, which included all variables.

According to the full model results, entry-level base pay is not significantly associated with firm size $\left(\beta_{3}=-218 p=0.37\right)$. Not only is the $p$-value greater than 0.05 , but also the sign of the effect is opposite the U.S.-based finding; firm size has a negative effect on entry-level pay in Japan. We also ran a regression using total assets, which is also a commonly used firm size measure, but the results are essentially the same; its effect is negative and insignificant. also examined the possibility that another variable mediates the effect of firm size on entry-level pay, but no such relationship was detected. These results suggest that in Japan, firm size is not positively related to entry-level pay, which supports hypothesis 1.

In contrast, the coefficient for firm performance is positive and significant $\left(\beta_{4}=240 . p<\right.$ 0.001). Thus, hypothesis 2 is not supported. Despite the high significance level, the effect size is minimal; even a 10 percent point (almost 2 standard deviations) increase in ROA is associated 
with only a 2,400 yen (= US\$19.3) increase in entry-level monthly pay. The coefficient of foreign ownership is also positive and significant $\left(\beta_{38}=197 . p<0.001\right)$, which supports hypothesis 4 . A one percentage-point increase in the proportion of firms' stock held by foreign owners is associated with an increase in entry-level base pay by 197 yen (= US\$1.59).

In Table 3, the increase in $R^{2}$ by adding industry dummy variables $\left(\triangle R^{2}=0.235\right)$ is highly significant $(p<0.001)$, which supports hypothesis 3a. Industry membership is related to the level of entry-level base pay. The findings using the large firm dataset and the small firm dataset are reported in Table 4 and 5, respectively. In both large and small firms, adding industry dummy variables significantly increases $R^{2}\left(\triangle R^{2}=0.660\right.$ for large firms and 0.168 for small firms, $p<0.001$ for both). The increase in $R^{2}$ is much greater in the large firm model. Industry membership accounts for 66 percent of the additional variance in entry-level base pay. This number is quite big as compared with other empirical studies estimating pay level (e.g., Gerhart \& Milkovich, 1990; Graham et al., 2000). These results offer reasonable support for hypothesis $3 b$, which states that industry membership explains the variance in entry-level base pay in large firms more than small firms.

\begin{tabular}{|c|c|c|c|c|c|c|c|}
\hline \multicolumn{8}{|c|}{$\begin{array}{c}\text { Table } 2 \\
\text { Descriptive Statistics and Correlations }\end{array}$} \\
\hline Variable & Mean & s.d. & 1 & 2 & 3 & 4 & 5 \\
\hline 1. Entry level base pay & 200,678 & 11,937 & & & & & \\
\hline 2. Firm size* & 6.95 & 1.21 & -0.05 & & & & \\
\hline 3. Firm performance & 1.13 & 4.84 & 0.16 & 0.01 & & & \\
\hline 4. Foreign ownership & 6.75 & 9.78 & 0.25 & 0.29 & 0.15 & & \\
\hline 5. Geography - Kanto & 0.53 & 0.50 & 0.27 & 0.07 & 0.00 & 0.18 & \\
\hline 6. Geography - Kansai & 0.23 & 0.42 & 0.02 & -0.05 & -0.01 & -0.06 & -0.59 \\
\hline
\end{tabular}




\begin{tabular}{|c|c|c|c|c|}
\hline \multicolumn{5}{|c|}{$\begin{array}{c}\text { Table } 3 \\
\text { Results of OLS Regression Analysis of Entry Level Base Pay (All Firms) }\end{array}$} \\
\hline Variable & Model 1 & Model 2 & Model 3 & Model 4 \\
\hline Geography - Kanto & $\begin{array}{r}10,257 \\
(746)\end{array}$ & $\begin{array}{r}10,344 \\
(734)\end{array}$ & $\begin{array}{r}5,545 \\
(639)\end{array}$ & $\begin{array}{c}4,953 \\
(678)\end{array}$ \\
\hline Geography - Kansai & $\begin{array}{c}7,583 \\
(881)\end{array}$ & $\begin{array}{c}7,569 \\
(868)\end{array}$ & $\begin{array}{r}3,560 \\
(793)\end{array}$ & $\begin{array}{r}3,332 \\
(780)\end{array}$ \\
\hline Firm size & - & $\begin{array}{l}-610 \\
(246)\end{array}$ & $\begin{array}{c}265 \\
(239)\end{array}$ & $\begin{array}{l}-218 \\
(245)\end{array}$ \\
\hline Firm performance & - & $\begin{array}{c}404 \\
(61)\end{array}$ & $\begin{array}{c}290 \\
(55)\end{array}$ & $\begin{array}{c}240 \\
(54)\end{array}$ \\
\hline Foreign ownership & - & - & - & $\begin{array}{c}197 \\
(29)\end{array}$ \\
\hline Industry dummy variables & Not included & Not included & Included & Included \\
\hline Intercept & $\begin{array}{c}193,454 \\
(621)\end{array}$ & $\begin{array}{r}197,188 \\
(1,813)\end{array}$ & $\begin{array}{r}194,965 \\
(1,769)\end{array}$ & $\begin{array}{r}197,505 \\
(1,780)\end{array}$ \\
\hline $\mathrm{N}$ & 1,382 & 1,382 & 1,382 & 1,382 \\
\hline$R^{2}$ & 0.121 & 0.151 & \multirow{2}{*}{$\triangle 0.235^{0.386}$} & 0.406 \\
\hline \multicolumn{2}{|l|}{$\triangle R^{2}$} & 0.030 & & $\triangle 0.020$ \\
\hline \multicolumn{5}{|c|}{ 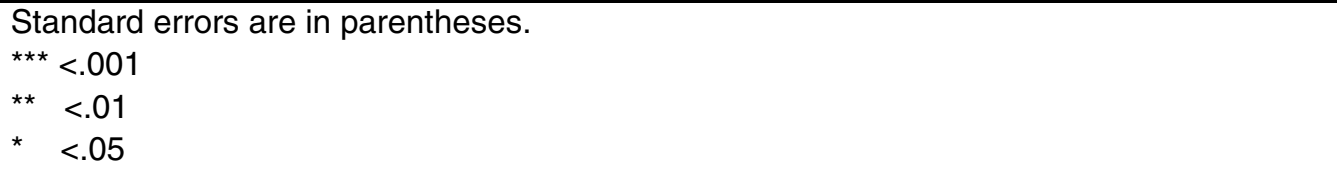 } \\
\hline
\end{tabular}

\begin{tabular}{|c|c|c|c|c|}
\hline \multicolumn{5}{|c|}{$\begin{array}{c}\text { Table } 4 \\
\text { Results of OLS Regression Analysis of Entry Level Base Pay (Large Firms) }\end{array}$} \\
\hline Variable & Model 1 & Model 2 & Model 3 & Model 4 \\
\hline Geography - Kanto & $\begin{array}{l}7,418 \\
(1,597)\end{array}$ & $\begin{array}{l}7,100 \\
(1,585)\end{array}$ & $\begin{array}{r}2,153 \\
(953)\end{array}$ & $\begin{array}{l}1,972 \\
(965)\end{array}$ \\
\hline Geography - Kansai & $\begin{array}{l}6,774 \\
(1,954)\end{array}$ & $\begin{array}{l}6,301 \\
(1,942)\end{array}$ & $\begin{array}{c}931 \\
(1,141)\end{array}$ & $\begin{array}{c}894 \\
(1,140)\end{array}$ \\
\hline Firm size & - & $\begin{array}{l}1151 \\
(907)\end{array}$ & $\begin{array}{l}590 \\
(544)\end{array}$ & $\begin{array}{l}384 \\
(571)\end{array}$ \\
\hline Firm performance & - & $\begin{array}{l}463 \\
(200)\end{array}$ & $\begin{array}{l}87 \\
(118)\end{array}$ & $\begin{array}{c}78 \\
(119)\end{array}$ \\
\hline Foreign ownership & - & - & - & $\begin{array}{l}46 \\
(39)\end{array}$ \\
\hline Industry dummy variables & Not included & Not included & Included & Included \\
\hline Intercept & $\begin{array}{r}195,002 \\
(1,381)\end{array}$ & $\begin{array}{r}184,711 \\
(8,102)\end{array}$ & $\begin{array}{r}194,576 \\
(4,829)\end{array}$ & $\begin{array}{r}195,7925 \\
(4,934)\end{array}$ \\
\hline $\mathrm{N}$ & 214 & 214 & 214 & 214 \\
\hline $\mathrm{R}^{2}$ & 0.095 & 0.123 & 0.783 & 0.785 \\
\hline$\triangle R^{2}$ & & 0.028 & $\triangle 0.660$ & $\triangle 0.002$ \\
\hline 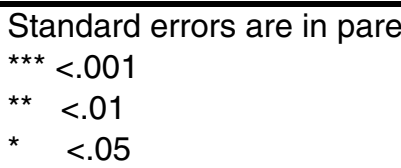 & ses. & & & \\
\hline
\end{tabular}




\begin{tabular}{|c|c|c|c|c|}
\hline \multicolumn{5}{|c|}{$\begin{array}{c}\text { Table } 5 \\
\text { Results of OLS Regression Analysis of Entry Level Base Pay (Small Firms) }\end{array}$} \\
\hline Variable & Model 1 & Model 2 & Model 3 & Model 4 \\
\hline Geography - Kanto & $\begin{array}{l}6,135^{* \prime} \\
(2,356)\end{array}$ & $\begin{array}{l}5,464 \\
(2,328)\end{array}$ & $\begin{array}{l}6,853^{*} \\
(2,493)\end{array}$ & $\begin{array}{l}5,038 \\
(2,445)\end{array}$ \\
\hline Geography - Kansai & $\begin{array}{c}1,872 \\
(2,521)\end{array}$ & $\begin{array}{c}2,543 \\
(2,468)\end{array}$ & $\begin{array}{c}4,632 \\
(2,778)\end{array}$ & $\begin{array}{c}4,101 \\
(2,678)\end{array}$ \\
\hline Firm size & - & $\begin{array}{l}-4,844 \\
(1,684)\end{array}$ & $\begin{array}{l}-3,493 \\
(1,751)\end{array}$ & $\begin{array}{l}-3346 \\
(1,686)\end{array}$ \\
\hline Firm performance & - & $\begin{array}{l}310^{*} \\
(111)\end{array}$ & $\begin{array}{c}195 \\
(114)\end{array}$ & $\begin{array}{c}137 \\
(110)\end{array}$ \\
\hline Foreign ownership & - & - & - & $\begin{array}{l}403 \\
(103)\end{array}$ \\
\hline Industry dummy variables & Not included & Not included & Included & Included \\
\hline Intercept & $\begin{array}{r}199,007^{* * *} \\
(1,924)\end{array}$ & $\begin{array}{c}223,669^{* * *} \\
(8,961)\end{array}$ & $\begin{array}{c}214,071^{* * *} \\
(9,375)\end{array}$ & $\begin{array}{c}213,146^{4 * *} \\
(9,029)\end{array}$ \\
\hline$N$ & 211 & 211 & 211 & 211 \\
\hline$\triangle R^{2}$ & 0.037 & $\begin{array}{l}0.093 \\
0.056^{*}\end{array}$ & $\triangle 0.168^{0.261}$ & $\triangle 0.058^{0.319}$ \\
\hline 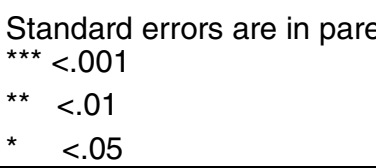 & & & & \\
\hline
\end{tabular}

\section{Post-hoc Data Examination - Pay Level Similarity within Industries}

Because our statistical analyses confirmed remarkable industry influences especially in large firms, we examined the base pay for entry-level jobs among established Japanese firms in the same industry more closely. Table 6 shows the examples of the pay levels of major firms in three financial industries: banking, securities \& commodity futures, and insurance. It shows strikingly similar patterns among the firms' entry-level pay in the same industry. For instance, the entry-level monthly base pay for each of 5 Japanese banks was 174,000 yen. In fact, 35 out of 63 firms in the banking industry paid 174,000 yen. The highest was 175,000 yen ( 2 firms) and the lowest was 170,000 yen ( 1 firm), so the range was only 5,000 yen (= US\$ 40.30) among 63 firms. Firms in the security \& commodity futures industry and insurance industry also show some similarity in their entry-level base pay. The security \& commodity futures firms paid either 
178,000 or 205,000 yen. Variation in pay level among insurance industry firms was rather small except for one firm (Aioi Insurance Co., Ltd.). In general, knowledge, skills, and abilities required in the banking, securities \& commodities futures, and insurance industries are relatively similar, so we argue that firms in these three industries would share the same labor market. Yet their pay levels appear to be different. They exhibited distinct patterns according to industry membership.

Morishima (1995) reported that the degree to which Japanese firms engaged in emerging human resource systems varied across industries. He found that firms in some industries were more likely to use new practices such as individualized career paths and contingent workers than other industries. Because of the potential difference in compensation management practices across industries, we also examined other industries: the electronics machinery industry and transportation equipment industry. As Table 7 shows, firms in the same industry offered virtually identical base pay for newly hired employees. Newly hired employees in NISSAN were paid exactly the same as those in TOYOTA even though the two firms showed a considerable difference in their market and financial performance (e.g., ROA for NISSAN was 10.46 percent while it was 2.47 percent for TOYOTA in 2000). Admittedly, the choice of industries and firms in Table 6 and 7 is arbitrary. We selected banking, securities \& commodity futures, and insurance industries to demonstrate that their entry-level base pay is strikingly similar among firms in each industry. The electric machinery and transportation equipment industries were selected because of brand reputation of firms outside Japan. Therefore, readers should not interpret the information in Table 6 and 7 as representative of all firms in our sample. Yet, we submit that inspecting the actual entry-level pay paid by these firms is informative. 


\begin{tabular}{|lcr|}
\hline \multicolumn{2}{|c|}{ Table 6 } & \\
\hline \multicolumn{2}{|c|}{ Company } & Industry \\
\hline & & $\begin{array}{c}\text { Monthly Base Pay } \\
\text { (in Yen) }\end{array}$ \\
\hline Sumitomo Mitsui Banking Corp., The & Banks & 174,000 \\
Asahi Bank, Ltd., The & Banks & 174,000 \\
Daiwa Bank, Ltd., The & Banks & 174,000 \\
Chuo Mitsui Trust \& Banking Co., Ltd., The & Banks & 174,000 \\
Bank of Yokohama, Ltd., The & Banks & 174,000 \\
& & \\
Daiwa Securities Group Inc. & Securities \& Commodity Futures & 178,000 \\
Mizuho Investors Securities Co., Ltd., The & Securities \& Commodity Futures & 205,000 \\
TSUBASA Securities Co., Ltd. & Securities \& Commodity Futures & 178,000 \\
Okasan Securities Co., Ltd. & Securities \& Commodity Futures & 205,000 \\
Sakura Friend Securities Co., Ltd. & Securities \& Commodity Futures & 205,000 \\
& & \\
Aioi Insurance Co., Ltd. & Insurance & 228,000 \\
Fuji Fire \& Marine Insurance Co., Ltd., The & Insurance & 202,800 \\
Nissay Dowa General Insurance Co., Ltd., The & Insurance & 201,500 \\
Sumitomo Marine \& Fire Insurance Co., Ltd., The & Insurance & 200,870 \\
Tokio Marine \& Fire Insurance Co., Ltd., The & Insurance & 200,860 \\
& & \\
\hline
\end{tabular}

\begin{tabular}{|c|c|c|}
\hline \multicolumn{3}{|c|}{$\begin{array}{l}\text { Table } 7 \\
\text { Entry Level Monthly Base Salary in } 2001 \text { - Manufacturing Industries }\end{array}$} \\
\hline Company & Industry & $\begin{array}{l}\text { Monthly Base Pay } \\
\text { (in Yen) }\end{array}$ \\
\hline Hitachi Ltd. & Electrical machnery & 201,000 \\
\hline Matsushita Electric Industrial Co., Ltd. & Electrical machnery & 201,000 \\
\hline Mitsubishi Electronic Corp. & Electrical machnery & 201,000 \\
\hline Sharp Corp. & Electrical machnery & 200,000 \\
\hline TOSHIBA CORP. & Electrical machnery & 201,000 \\
\hline NISSAN MOTOR CO., LTD. & Transportation Equipment & 200,000 \\
\hline ISUZU MOTORS LTD. & Transportation Equipment & 199,000 \\
\hline TOYOTA MOTOR CORP. & Transportation Equipment & 200,000 \\
\hline MITSUBISHI MOTORS CORP. & Transportation Equipment & 200,000 \\
\hline Fuji Heavy Industries Ltd. ${ }^{*}$ & Transportation Equipment & 200,000 \\
\hline
\end{tabular}

\section{Discussion}

This paper investigated the determinants of entry-level pay for college graduates in Japanese firms. Building on U.S.-based theory and research, we explored whether the factors that have been found to be influential to pay levels in the U.S. also explain the variance in entry- 
level pay in Japan. Due to our focus on firm-level and industry-level factors, we consider this study a special case of inter-firm pay differential research. Because the data analyzed was for entry-level jobs, we incorporated the role of pay in attracting job applicants. The use of Japanese firms' data required us to take account of the Japanese employment context and its compensation management practices.

Our analyses revealed that the findings of U.S. studies cannot be directly exported to Japanese firms. In the Japanese companies we analyzed, size was not positively related to entry-level pay. Firm performance was positively associated with entry-level pay; however, its contribution to our statistical model was minimal. Adding size and performance variables simultaneously increased $\mathrm{R}^{2}$ only by 0.03 . In contrast, industry membership variables substantially improved our model; $R^{2}$ increased by 0.235 , suggesting that industry membership accounted for about one quarter of the variance in entry-level base pay (Table 3).

The effect of industry membership was much more robust when we analyzed only large firms (Table 4). Industry membership variables explained more than 65 percent of the variance in entry-level base pay in Japan. When we drilled down into the data, we found firms in the same industry often paid exactly the same level of base pay. We believe that this was due to the nature of Japanese firms' pay information exchange practices with market competitors. Because of their difficulty in acquiring relevant market pay data, weak employment brand status, and limited employment security, foreign MNCs operating in Japan paid more than traditional Japanese firms to attract job applicants.

Our analyses rejected the notion that large Japanese firms pay more to their employees at the entry-level base pay. If we take account of the role of entry-level pay, particularly attracting job applicants, and Japanese long-term employment security, U.S.-based explanations are less convincing. In contrast, our research unexpectedly confirmed the positive effect of firm performance on entry-level base pay in Japanese firms. We are not quite certain why firms with better performance should pay more even though they have less difficulty in attracting job applicants. One possible explanation is compensation managers' prevalent perception that firms 
should make generous pay table updates when their firms perform well. A qualitative study by Levine (1993) reported that U.S. compensation managers perceived that well-performing firms should make generous pay increases. Similarly, in the 1999 Japanese Ministry of Labor survey on the factors Japanese corporate managers consider when updating their pay tables, 81.5 percent of managers reported firm performance to be the most important factor in pay table updates (Japan Ministry of Labor, 2000). As a result of the pay table update, the pay level for entry-level jobs as well as other jobs may be raised in response to improved firm performance.

As we noted, this study is regarded as a special case of inter-firm pay differentials research. We found that there was very little pay differential across firms within an industry in Japan. Instead, we observed a distinct industry pattern; the variance in pay level was largely explained by industry membership. We believe that this was the result of the Japanese firms' unique practice, namely sharing information, including future expectations and intentions among market industry competitors. It is important to note that our argument draws on interviews with a very limited number of Japanese compensation managers. We also note that our empirical analyses did not directly test whether the striking similarity in entry-level base pay among Japanese firms was caused by information sharing. Rather we inferred from the data. There may be competing explanations (e.g., Japanese labor market is perfectly competitive). Hence, further research, especially qualitative research, is clearly required to further the understanding of pay determination in Japan. In addition, while we believe that information exchange is conducted by firms competing in the same market, information exchange may be conducted among firms in the same keiretsu (Namiki, 1999). If this is so, firms in the same keiretsu may set a similar level of entry-level base pay, and therefore keiretsu membership explains the variance in entry-level pay in Japan. Exploring this issue, both by both qualitative and quantitative research, will also help researchers to untangle the determinants of employee compensation in Japanese firms.

Regardless of the manner in which industry membership influences Japanese firms' entrylevel base pay, our results imply that Japanese firms' strategic perspective is to minimize pay 
competition among firms within an industry - at least for hiring new employees. Compensation research based on U.S. data suggests that there are stable firm differences in pay levels even within an industry (Gerhart \& Milkovich, 1990). Management has the discretion in its compensation choices to gain and sustain competitive advantage (Milkovich \& Newman, 2002). Because firms' intentions for achieving competitive advantage vary, their compensation systems differ. In contrast, Japanese firms simply pay the same amount as their competitors. In some sense, this is not strategic, at least at the firm level. Nor does it help specific firms attract high quality human capital, which strategic human resource management researchers argue is a major role of human resource practices (Wright, McMahan, \& McWilliams, 1994).

While our empirical analysis clearly showed that pay level is largely explained by industry membership in Japan, this study did not delve into what determines industry-wide pay levels. Why do the insurance industry pay more than the banking industry as shown in Table 6 ? It would be interesting to see if there are any industry-level variables that explain inter-industry pay differentials (e.g., market competition, union density, industry growth). In addition, if collusion does really exist, firms in the information exchange group might jointly develop an industry-wide (or group-wide) pay strategy to attract top college graduates. If this is the case, the most relevant unit of analysis when examining compensation strategy in Japan will not be firm-level, but industry-level. Thus, more research that focuses on industry-level factor is necessary in Japan.

Clearly, one implication of our study is that the determinants of pay found to be relevant in U.S. studies may not necessarily hold in other countries. While U.S.-based research repeatedly found a positive relationship between firm size and employee pay levels, this relationship was not supported in our study using entry-level base pay in Japanese firms. Thus, both researchers and practitioners need to reconsider their theoretical rationales in the local employment contexts that they are studying. Furthermore, even if a factor is found to be influential both in the U.S. and other countries, the mechanism by which the influence works may be different. As we 
discussed, both in the U.S. and Japan, industry membership matters; however, how industry membership influences employee pay level appears to differ.

Our study has furthered our understanding of entry-level pay. It is widely acknowledged that pay is an important component of a firm's HRM system to attract job applicants (Barber \& Bretz, 2000). Yet, most studies are laboratory experiment or policy capturing studies, and thus little is known about how firms actually set their pay levels for new employees. As we discussed, the determinants of entry-level pay may be different from overall employee pay level even in the U.S. because entry-level pay has a very specific purpose, namely attracting job applicants. We believe that studying entry-level pay using real company pay data will improve our understanding of managing compensation and staffing.

We recognize shortcomings with our study. First, we only examined base pay. Employee compensation comes in many forms such as bonuses, allowances, and employee benefits. Using total compensation date would definitely improve the accuracy of our empirical analysis. Second, although we argued that entry-level pay is critical for attracting top talent, college graduates may also look at future pay prospects. It might be especially true in Japanese firms given the strong expectation for Japanese employees to stay in a single firm. College graduates may pay greater attention to future pay growth or their lifetime earnings rather than just looking at entry-level pay. Though the difficulty of collecting pay information from Japanese firms (except for entry-level pay) makes it extremely difficult to include future pay prospects information, college graduates' expectation of future earnings needs further study.

In sum, our study contrasted the difference in pay setting between Japanese firms and U.S. firms. Due to the difference in employment context and compensation management practices, the determinants of pay level differ in the two countries. This exemplifies the importance of incorporating local employment contexts when applying theory and research developed in other countries. Our study also calls for further studies on entry-level pay. The focus on entry-level pay will provide a different perspective on the role of pay in attracting high quality human capital. 


\section{References}

Abegglen, J. C. (1958). The Japanese factory: Aspects of its social organization. Glencoe, IL: Free Press.

Ahmadjian, C. L., \& Robinson, P. (2002). "Safety in numbers: Downsizing and the deinstitutionalization of permanent employment in Japan." Administrative Science Quarterly, 46: 622-654.

Barber, A. E., \& Bretz, R. D., Jr. (2000). "Compensation, attraction, and retention.” In S. Rynes, \& B. Gerhart (eds.) Compensation in organizations: Current research and practices. San Francisco, CA: Jossey-Bass

Bloom, M. (1999). The performance effects of pay dispersion on individuals and organizations. Academy of Management Journal, 42: 25-40.

Bloom, M., Milkovich, G. T., \& Mitra, A. (2000). Toward a model of international compensation and rewards: Learning from how managers respond to variations in local host contexts. Center for Advanced Human Resource Studies Working paper series 00-14. Cornell University, Ithaca, NY.

Bretz, R. D. Jr., \& Judge, T. A. (1994). "The role of human resource systems in job applicant decision process." Journal of Management, 20: 531-551.

Brown, J. (1989). Why do wages increase with tenure? American Economic Review, 79: 971-991.

Card, D. (1999). The causal effect of education on earnings. In O. Ashenfelter \& D. Card (eds.). Handbook of Labor Economics, vol. 3A.

Cable, D. M., \& Judge, T. A. (1994). "Pay preferences and job search decisions: A personorganization fit model." Personnel Psychology, 43: 317-348.

Cortina, J. M. (2002). Big things have small beginnings: An assortment of "minor" methodological misunderstandings. Journal of Management, 28: 339-362.

Dore, R. (1973). British factory Japanese factory: The origins of national diversity in industrial relations. Berkeley. University of California Press.

Evans, P., Pucik, V., \& Barsoux, J. (2002). The global challenge: Frameworks for international human resource management. New York. NY. Irwin.

Ehrenberg, R. G., \& Smith, R. (1997). Modern labor economics (6th ed.). Addison-Wesley.

Eisenhardt, K. M. (1988). "Agency and institutional theory explanations: The case of retail sales compensation." Academy of Management Journal, 31: 488-511.

Frick, R. W. (1995). Accepting the null hypothesis. Memory \& Cognition, 23: 132-138.

Gedajlovic, E., \& Shapiro, D. M. (2002). "Ownership structure and firm profit ability in Japan." Academy of Management Journal, 45: 565-575.

Gerhart, B., \& Milkovich, G. T. (1990). "Organizational differences in managerial compensation and financial performance." Academy of Management Journal, 33: 663-691.

Graham, M E., Hotchikiss, J. L., \& Gerhart, B. (2000). Discrimination by parts: A fixed effects analysis of starting pay differences across gender. Eastern Economic Journal, 26: 9-27.

Groshen, E. L. (1991). Sources of intra-industry wage dispersion: How much to employers matter? The Quarterly Journal of Economics, 106: 869-884.

Groshen, E. L., \& Levine, D. I. (2000). The rise and decline (?) of employer wage structures. Federal Reserve Bank, NY.

Jensen, M. C., \& Meckling, W. H. (1976). "Theory of the firm: Managerial behavior, agency costs and ownership structure." Journal of Financial Economics, 3: 305-360.

Kato, T. (2001). "The end of life time employment in Japan?: Evidence from national surveys and field research." Journal of Japanese and International Economics, 15: 489-514.

Kato, T., \& Rockel, M. (1992). "Experiences, credentials, and compensation in the Japanese and U.S. managerial labor markets: Evidence from new micro data." Journal of the Japanese and International Economies, 6: 30-51.

Kerr, J., \& Bettis, R. (1987). Boards of directors, top management compensation and shareholder return, Academy of Management Journal, 30: 645-664.

Koch, M. J., \& McGrath, R. G. (1996). "Improving labor productivity: Human resource management policies do matter." Strategic Management Journal, 17: 335-354. 
Kruger, A. B., \& Summers, L H. (1988). Efficiency wages and the inter-industry wage structure. Econometrica, 56: 259-293.

Levine, D. I. (1993). Fairness, market, and ability to pay: Evidence from compensation executives. American Economic Review, 83: 1241-1259.

Martocchio, J. J. (2001). Strategic compensation: A human resource management approach. Prentice Hall: Upside River, NJ.

Milkovich, G. T., \& Newman, J. (2002). Compensation (7th ed.). Homewood, IL: Irwin.

Ministry of Labor, Japan (2000). Rodo Hakusho [White paper on labor] Tokyo, Japan. (in Japanese).

Mishina, O., \& Inaba M. (1985). The integrated wage and salary system: A guide to Japanese wage and salary systems at present and for the future. The Institute of Labor Administration: Tokyo

Morishima, M. (1995). "Embedding HRM in a social context." British Journal of Industrial Relations, 33: $617-640$.

Namiki, N. (1999). "Parent-subsidiary relationships in Japan: Some observations from financial statement data." SAM Advanced Management Journal, 64: 15-19.

National Personnel Authority. (2001). Minkan Kyuyo no Jittai. [Current status of private firms' remuneration systems] (in Japanese).

Tachibanaki, T. (1996). Wage determination and distribution in Japan. Oxford University Press: New York.

The Nihon Keizai Shimbun. (2001). Nendo Saiyo Keikaku. [Recruit plan survey, Fiscal Year 2001]. April 23. (in Japanese).

The Nihon Keizai Shimbun. (2002). Nendo Saiyo Keikaku. [Recruit plan survey, Fiscal Year 2001]. May 23. (in Japanese).

Okazaki, K. (1997). "Measurement of Japanese Lifetime employment system." In Sano, Y., Morishima, M., \& Seike, A. (eds.) Frontiers of Japanese human resource practices. Tokyo, Japan: Japan Institute of Labor.

Olian, J. D., \& Rynes, S. L. (1984). "Organizational staffing: Integrating practice with strategy." Industrial Relations, 23: 170-183.

Pfeffer, J., \& Davis-Blake, A. (1987). Understanding organizational wage structures: A resourcedependence approach. Academy of Management Journal, 30: 437- 455.

Powell, G. N. (1984). "Effects of job attributes and recruiting practices $n$ applicant decisions: A comparison." Personnel Psychology, 37: 721-732.

Rynes, S. L. (1987). “Compensation strategies for recruiting.” Topics in Total Compensation, 2: 185196.

Sano, Y. (1995). Human resource management in Japan. Tokyo, Japan: Keio University Press.

Schlender, B. R., \& Kano, C. (1994). "Japan's white collar blues." Fortune, March 21: 97-101.

Shapiro, C., \& Stlglitz, J. E. (1984). "Equilibrium unemployment as a worker discipline device." American Economic Review, 74: 433-444.

Shibata, H. (2000). "The transformation of the wage and performance appraisal system in a Japanese firm." International Journal of Human Resource Management, 11: 294-313.

Terpstra, D. E., \& Rozell, E. J. (1993). "The relationship of staffing practices to organizational level measures of performance." Personnel Psychology, 46: 27-48.

Topel, R. (1991). Specific capital, mobility, and wages: Wages rise with seniority? Journal of Political Economy, 99; 145-176

Tosi, H. L., Werner, S., Katz, J. P., \& Gomez-Mejia, L. R. (2000). "How much does performance matter? A meta-analysis of CEO pay studies." Journal of Management, 26: 301-339.

Toyo Keizai (2001). Japan company handbook, Summer, 1st edition.

Toyo Keizai (2001). Japan company handbook, Summer, 2nd edition.

Tower's Perrin Tokyo and Nikko Cordial Securities (2002). Stock option donyu gaikyo [The current state of the use of stock options]. (in Japanese).

Walsh, M. W. (2001). Roughnecks wrangle for more money. The New York Times, January 10.

William Mercer. (2001) Cost of living reports.

Wright, P. M., McMahan, G. C., \& McWilliams, A. (1994). Human resources and sustained competitive advantage: a resource-based perspective. International Journal of Human Resource Management, 5: 301-326. 


\section{Endnotes}

'For instance, employers are legally mandated to pay half of employees' social security premiums. Premium calculation is based on the employees' base pay; bonuses and allowances are excluded. Similarly, overtime allowances are calculated based on base pay.

ii The exchange rate was 1 US dollar $=124.06$ yen as of April 2001 (Bank of Japan).

iii We also used logged firm size variables, but the results didn't change. 